\title{
DESIGN AND IMPLEMENTATION OF AGROBOT BY USING IOT
}

\author{
Shikha Sharma, Prateek Singh, Vaibhav Singh, Prabhat Kumar Srivastava \\ Department of IT \\ Inderprastha Engineering College \\ Ghaziabad, U.P., India \\ Dr. Kamal Upreti \\ Department of IT \\ Inderprastha Engineering College \\ Ghaziabad, U.P., India
}

\begin{abstract}
Agrobot is an autonomous robot that performs the farming techniques and will help farmers in the farming land. This robot will be controlled by Arduino that will perform the farming processes such as ploughing, seed dispensing and harvesting. It could replace conventional farming mechanism in the third world century. As we know in conventional farming domestic animals are still used in rural villages and they suffer a lot. They use old instruments, they use biofertilizers manually and they do not produce high productions. The growing human population has shrunken the agricultural sources which results in less people in farming field and more in urban areas. Thus, it is mandatory to discover new methods to upgrade efficiency of agriculture worldwide. This led to increased interest and spending in field of Agriculture Robotics. This new way of farming in which robots will be used to overcome all those problems that occurs in traditional farming. It includes machines and new instruments and they will be going to produce high productions. By keeping the less man power and increased productivity rate in mind, the designing of this Agrobot is done so that it can perform all the farming process on its own. To check the environmental conditions like humidity, wetness of soil etc is its major advantage rather than only increasing the productivity. The approach of developing this smarter machine will surely gonna change the traditional methods of farming by taking this agricultural field into a new modern phase.
\end{abstract}

Keywords - Agrobot, conventional farming, Robotics, Productions, worldwide, Ploughing, Harvesting.

\section{INTRODUCTION}

In India, approx. $70 \%$ people are liable upon agriculture (the major resource to survive).[10] On comparison with other fields, development in agricultural area is less. So, it is mandatory to do some enhancement in this field. The main objective to developing agricultural technology is to minimize the labor force, a phenomenon which common in the whole world. Another reason is to improve food quality.[10]

Nowadays, agricultural operations like ploughing, harvesting can be done automatically and as there is accessibility of automatic machines like robots. For making of robot, one has to consider two important contemplations which are exact requirement for the field and environmental conditions in which robot have to work for automating the operations of agriculture.

Use of robotics in various modes of agriculture will assist the farmers in giving better outcomes of productivity. Currently farmers are way behind from these consequences due to disuse of robotic machines in agricultural fields. Traditional methods in India are hugely dependent on labor force for dragging, lifting, weed control, fruit picking, etc. Farmers are prone to work in the disastrous environment while spraying chemicals and pesticides. While tractors compress the filthy land as they are bulky and huge and cannot make movement in terrain conditions. These approaches decline to differentiate the harvest and soil in closeness.

A robotized and innovative agrarian framework is epitomized from above issues. Robots can work restless in every condition according to advisable program to perform the required work with computerized help. The major advantage of light weight robots is that they do not suppress the filthy land.

Following are the modes of operations that will going to be perform by this autonomous farming robot: -

\section{A. MODE-1}

It is seed dispensing mode and in this the seed dispersion takes place with obstacle monitoring in parallel. Here a RPM motor is connected at the back of robot where the dispenser is present. The appropriate time at which the seed handler will 


\section{International Journal of Engineering Applied Sciences and Technology, 2020 Vol. 5, Issue 1, ISSN No. 2455-2143, Pages 319-325 \\ Published Online May 2020 in IJEAST (http://www.ijeast.com)}

vibrate has been programmed in the Arduino programming, hence this controls the seed flow from the seed dispenser so that there is no seed wastage.

\section{B. $M O D E-2$}

It is the harvesting mode where the crops are harvested. The harvester is created in cylindrical like structure which rotates and harvests the crops. The rotation is provided by A RPM DC motor which is connected to the side of harvester. L298D connects this mode to Arduino. Program coded in Arduino controls the rotation speed and other specifications too.

\section{MODE-3}

This is ploughing mode. In this ploughing is done with the help of plough which is made up of jagged teeth. Proper stable space is given to the seeds for settling up in a proper line in the soil.

\section{LITERATURE SURVEY}

Automation in the field of agriculture with the help of robot is a trial to bring agricultural within the field of robotics and automation. The intension is to reduce the workload of labors on the fields. An algorithm is to be implemented which will enable the robot to carry out zonal tilting, ploughing, seeding and harvesting. The user will give the dimensions (length and breadth) of the sphere. Microcontroller will input these parameters into the algorithm and the work will be etched accordingly. Zonal tilting could be one of the farming techniques during which a niche is left between the two lines of cultivation. This can be done to maintain soil nutrients and $\mathrm{pH}$ levels with the help of proper irrigation. The algorithm of robot was used on various platforms like farming simulator 2017, java and implemented on Arduino.[6]

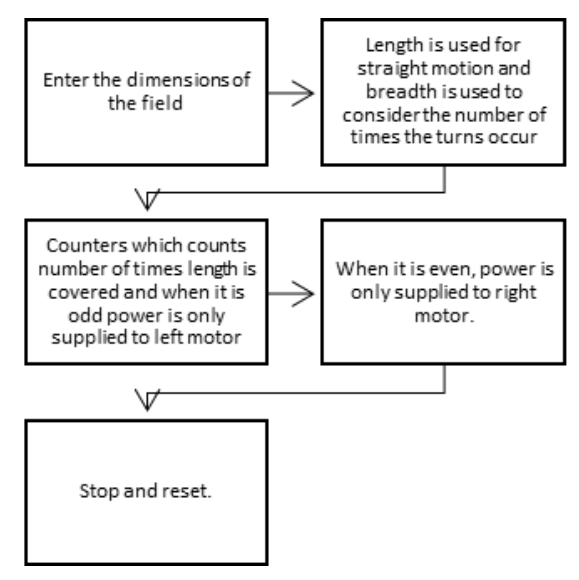

Fig 1: Flow Chart of Automation algorithm
The Agrobot paper elaborates the design implementation and experiments of Agrobot. The target of projects to form an agricultural robot which can perform all the essential farming activities like sowing, ploughing, sprinkling . The execution of Agrobot saves lots of time, capability, human effort, resource wastage and also it works at less expensive cost.[9] Automatic ploughing and seeding robot paper gives that almost all of those systems which work independently are more liable than conventional systems. the advantages of reduction parturient prices and conditions on the number of routine hours of working has been increased significantly due to which automation of diverse working routines is possible. Yet some have failed because of indispensability of accuracy of specific tasks.12]

AG-Robot Design and Analysis to Light Weight has body frame of made of glass fiber, whose strength to weight ratio is high compared to the conventional materials like steel or aluminum. Product is familiar with maize crop and it may further upgrade for the other crops. It is capable of doing seeding cutting harvesting and other agricultural tasks. [7]

Sensor based Agrobot for Sowing seeds is a robot which is designed for agricultural purposes such as seeding, cutting, harvesting etc. Main objective of this machine is to lessen the labor burden and expand the pace and precision of the work. Introduction of a product which is a resultant of arrangement and creation of movable robot for agricultural area is done in this paper. Here infrared and ultrasonic sensors are used for proper navigation and detection of obstacles as well as use of humidity sensor is also done here to measure the soil moisture. The foremost task of this robot is sow seeding.[8]

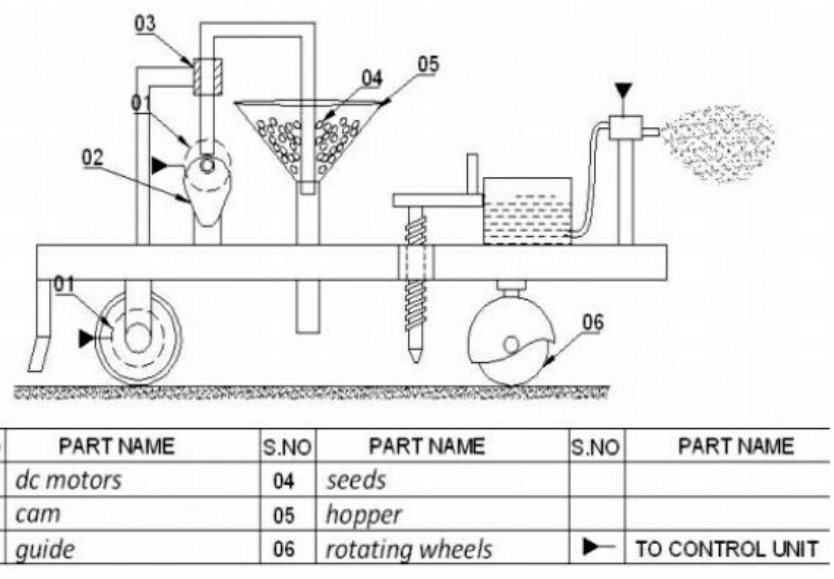

Fig 2: Fabrication of seed sowing robot.

In Robotic Famer, the robot model is made in such a way that it can process the farming area by using no human effort. The objective to develop this robot is to lessen the human effort, time and increase the rate of productivity and help the cultivators. This autonomous robot is used to plough the land, sowing of the seeds and spraying of fertilizers and harvesting of the crops using microcontroller.[2] Comparison between manual and farming using tractor is as follows: 


\begin{tabular}{|l|l|l|l|l|}
\hline S.no. & Parameters & Manual & Tractors & $\begin{array}{l}\text { Seed } \\
\text { Dispensing } \\
\text { by robot }\end{array}$ \\
\hline 1. & $\begin{array}{l}\text { Human } \\
\text { effort }\end{array}$ & High & Medium & No \\
\hline 2. & $\begin{array}{l}\text { Time } \\
\text { needed }\end{array}$ & High & Medium & Low \\
\hline 3. & $\begin{array}{l}\text { Seed } \\
\text { Dispensing } \\
\text { technique }\end{array}$ & $\begin{array}{l}\text { Convention } \\
\text {-ally }\end{array}$ & $\begin{array}{l}\text { Convention } \\
\text {-ally }\end{array}$ & $\begin{array}{l}\text { Automatic } \\
\text {-ally }\end{array}$ \\
\hline 4. & $\begin{array}{l}\text { Energy } \\
\text { needed }\end{array}$ & High & High & Low \\
\hline
\end{tabular}

In this Agriculture Robotics: Practicality and Feasibility, our main focus is on practical and feasibility study of the agriculture robot. After inspection, the author declares that the robot isn't dependent only on advances but it's dependent on infrastructure too. Through this infrastructure all the services and technologies are provided that marks wireless communication, human-robot interaction (HRI), and software sharing framework. If such infrastructure is not there then advanced design will be unable to hold agobot's practicality and feasibility. Many organizations can't allow the technological and monetary cost of building such infrastructure, which leads the robot uneconomical. The conclusion is to search out a practical and feasible robot and also to search out a value effective and reliable approach that leads such infrastructure for agriculture robots.[3]

Agricultural robot -an economic feasibility explains the commercial practicability of using autonomated robot as compared to conventional method in different areas is explained through agricultural robot as: weed detection in high rated crops and grass cutting of cereals. The comparison done is with the help of system analysis and feasibility study by individual for these three applications. The results of all the three frameworks cleared the picture that the robot applications are way more economically practical than the ancient/ traditional methods. The forfeit of robotic systems are increased because of less vehicles space and more price of real time Global Positioning System (RTK-GPS). [11]

GSM based Automated Irrigation Control using Rain gun Irrigation System has extensive work on automated feed machine in cultivator rotatory blade welding machineries. It can achieve placement and the feeding of every blade carriers and also make sure that the blade carrier coordinate automatically. Moreover, the major benefit of it is easy to use and less price.[15]

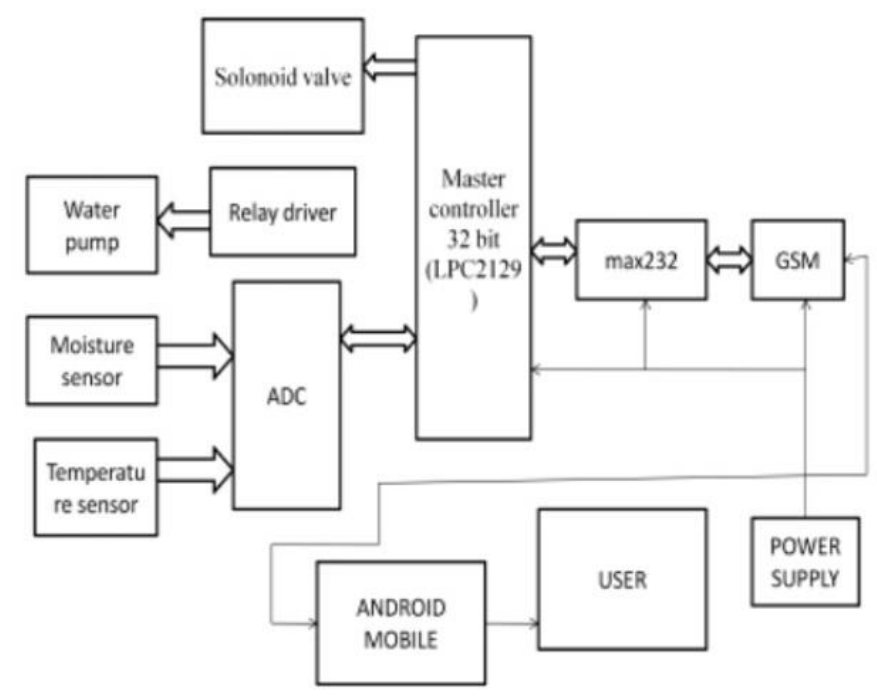

Fig 3: Block diagram for proposed system

To achieve high uniform sowing patterns, seeder is designed as this paper tells about the crop establishment for seed grading. Keeping it in mind an active seed grinder and a planter to punch were manufactured. Grid seeding measurements are done in an absolute manner. However, mode testing have to be done in the field to test the effectiveness and results under tough and extreme conditions. Therefore, testing is done by connecting the four seed grids in front of the tractor and then operating it. [14]

\section{METHEDOLOGY}

The main objective of our project is to build a multithreaded agricultural robot, which can be used for agricultural processes like ploughing, seed dispensing, harvesting(crop cutting) and also irrigate the system. Keeping in mind less price and more efficient.

- Front part of the model is used for harvesting. The harvester is attached to a DC motor which has more than 700rpm.[10] The harvester is made up of Iron sheet.

- Back end of the model is used for dig down process. For digging process iron nail teeth like structure are used. This mode operates when selected by the user.[10]

- A cylindrical like structure that is going to drop the seeds at farming land. This model is made up of acrylic sheet and the seeds will pass through this cylindrical like shape through the drilled hole on the lower level to the digging soil.

- In Order to design the interface for agricultural process, a PCB circuiting is implemented. Arduino (a Microcontroller), At mega 328p is the main component for performing the processes. The 


\section{International Journal of Engineering Applied Sciences and Technology, 2020 \\ Vol. 5, Issue 1, ISSN No. 2455-2143, Pages 319-325 \\ Published Online May 2020 in IJEAST (http://www.ijeast.com)}

design system of Circuit, is as such it controls two DC motor that is powered by motor driver L293D, and with the power supply that comprises of a voltage regulator $(5 \mathrm{~V}-12 \mathrm{~V})$. Arduino uno interfaces and controls the circuitry defined above. Arduino uno is used because of its one of the properties to implement logical programing.

- We added an additional motor for irrigation purpose. A sensory chip is attached to the motor that gives the data about the condition of soil, like how much humidity is there., things like that.

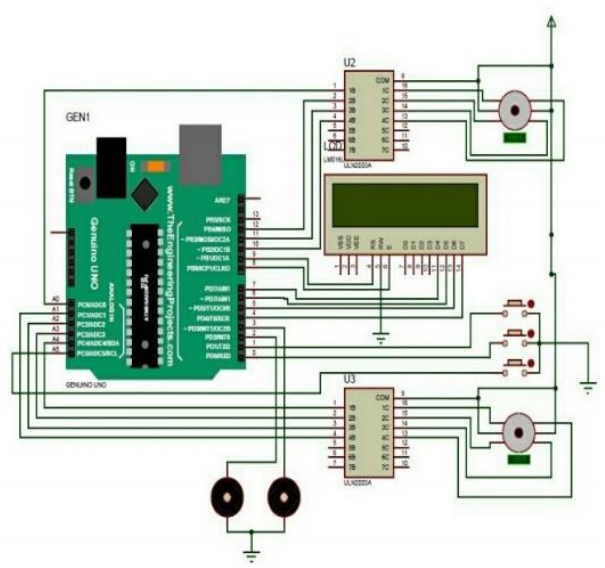

Fig 4: Internal circuit diagram

Basic agricultural functions (ploughing, seeding, harvesting) This Autonomous farming robot (AFR) constitute of performing activities that are mainly done while practicing farming. The AFR simply moves and perform the agricultural activity as programmed. And in order to stop the activity, it gets disabled when the job is done.

And that's how we combined these functionalities with our mechanism to map all the requirements that was proposed.

As soon the robot stops, the sprinkler comes into play and waters the land till the required amount.The movement of the robot is controlled using four high torque 100RPM DC motors.

The farmer will be providing with all the dimensions of field area as the input. The three modes will be ploughing, seed dispensing and harvesting. Through the length and breadth complete distance covered by the robot will be fixed. It may be multiplication of length and breadth. The algorithm states that the length as the distance that needs to be covered by the robot in a single run. Once the distance is reached, the robot takes a round turn, precisely speaking a supplementary turn. After the turn is made, the robot continues to go in a single line until the dimensions are covered. The algorithm is used to accomplish the precession agriculture methodology. This method is used as follows.

The steps of implementation are:

1. Enter the length.

2. Enter the breadth.

3. Selection of mode.

4. In Arduino, the values are entered.

5. Execution takes place.

6. Reset once the execution is completed.[6]

The dimensions (length and breadth) of the fields are to be entered when it is programmed in Arduino and after providing the dimensions of field, mode is to be selected in which the robot is going to perform:

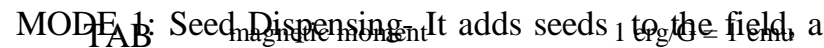

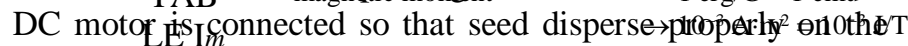
land. $M \quad$ magnetization $\quad 1 \mathrm{erg} /\left(\mathrm{G} \cdot \mathrm{cm}^{3}\right)=1 \mathrm{emu} / \mathrm{cm}^{3}$

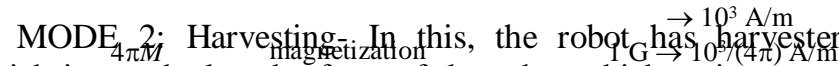

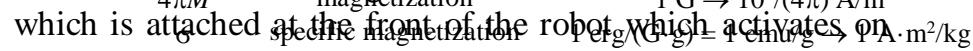
mode 2. magnetic dipole $1 \mathrm{erg} / \mathrm{G}=1 \mathrm{emu}$ moment $10 \times 10^{-10} \mathrm{~Wb} \cdot \mathrm{m}$

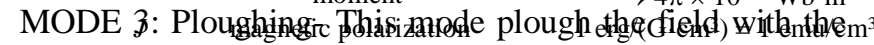
teeth like iron nails structure fixed at the back end- $\oplus$ the litobst.

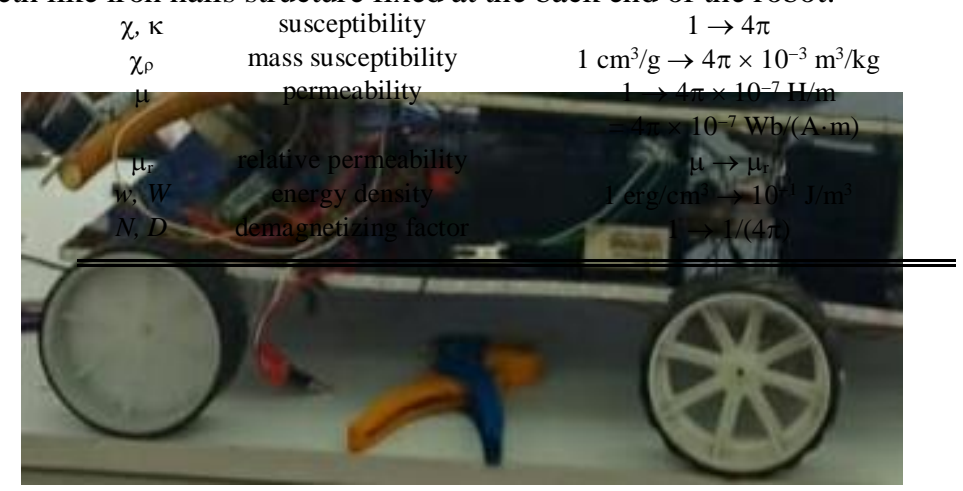

Fig 5: Agrobot

IV. RESULTS

We operate our robot on a small land. We placed some marks and obstacles conventionally. The robot tested appropriately by successfully analyzing the field area and performed the three main features that we have planned initially in the project (ploughing, harvesting and seed dispensing). Once the processes are performed it returns back at its position. 


\section{International Journal of Engineering Applied Sciences and Technology, 2020 \\ Vol. 5, Issue 1, ISSN No. 2455-2143, Pages 319-325 \\ Published Online May 2020 in IJEAST (http://www.ijeast.com)}

The processes are as follows:

1. Seed Dispensing: The seed dropping is done using the dc motor which vibrates when the robot starts moving. This DC motor is attached with a rectangular shaped funnel like structure at the back side of the robot. The DC motor has more than 700rpm and because of this it creates vibration, and with the help of this seeds inside the funnel to drip consecutively.

2. Harvesting: For this, a simple harvester is connected to the single dc motor which is used to perform the mode of harvesting the crop. The harvester is placed at the front side of the robot. Within the structure of harvester, whose structure is like twisted blade In cylindrical rollers (just like 6 bat reel in combined harvestor), a DC motor is attached in order to keep the harvestor rolling and cutting the crops. Based on this, it can be upgrade with help of new hardware.

1. Ploughing: This mode is achieved by attaching the jagged teeth like structure made up of iron nails at the back side of the robot. For this we need a good physical power to the robot, because it has some weight and when it is placed on field for ploughing procedure, it needs more strength to move forward. This mode is the first mode to be performed as soon as the robot starts Once its on the field, it continuously ploughs the soil through the Plougher which is powered by $12 \mathrm{~V}$ DC. [10]

2. Irrigation: An isolated irrigation system model is developed similar to a water sprinkler to check the different rate of water when there is dry soil. DC motor controls the sector angles and trajectory of the water jet.

The statistical data measured and recorded on different types of field are as follows:

\begin{tabular}{cccc}
\hline $\begin{array}{c}\text { Types of } \\
\text { Farming } \\
\text { done }\end{array}$ & Condition & $\begin{array}{c}\text { Real time } \\
\text { data } \\
\text { (harvesting } \\
\text { and } \\
\text { ploughing) }\end{array}$ & $\begin{array}{c}\text { Results (in } \\
\text { degree } \\
\text { Celsius }\end{array}$ \\
\hline Agroforestry & $\begin{array}{c}\text { More } \\
\text { humidity }\end{array}$ & yes & +10 \\
\hline
\end{tabular}

$\begin{array}{cllr}\begin{array}{c}\text { Crop rotation } \\ \text { field }\end{array} & \begin{array}{l}\text { Moderate } \\ \text { humidity }\end{array} & \text { yes } & +9 \\ \begin{array}{c}\text { Mixed/Inter } \\ \text { Cropping }\end{array} & \begin{array}{l}\text { Moderate } \\ \text { humidity }\end{array} & \text { yes } & +9 \\ \text { Polyculture } & \begin{array}{l}\text { Highly } \\ \text { harming }\end{array} & \text { yes } & +10 \\ \text { humid } & & \\ \text { Water } & \text { Highly } & \text { yes } & +10 \\ \text { hamid } & & \end{array}$

Average humidity

More

Than

10

Hence, all three modes have been checked properly and tested. All the modes work successfully. Mode 1 shows the proper functioning of seed dispenser. The seeds get dispensed in a proper line drawn by the jagged teeth of the plough. Below shows the image of seed dispensed in the proper line.

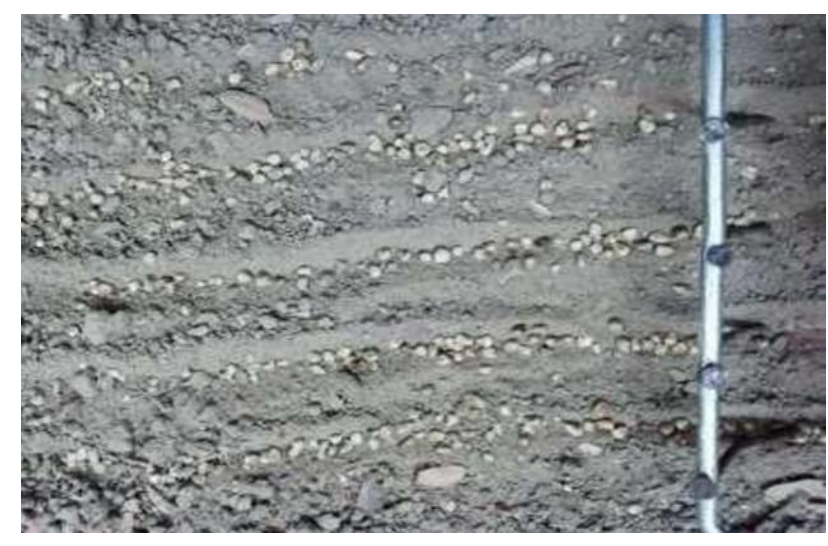

Fig 6: Result of seed dispenser

$$
\text { V. PROBLEMS FACED }
$$

Throughout our project we faced many issues and examines accordingly.

- Difficulty on motors

- Troubleshoot on controlling motor

- Wheels are not big enough to handle the weight [1] 


\section{International Journal of Engineering Applied Sciences and Technology, 2020 Vol. 5, Issue 1, ISSN No. 2455-2143, Pages 319-325 \\ Published Online May 2020 in IJEAST (http://www.ijeast.com)}

\section{BENEFITS}

We tried to make the agrobot as feasible as possible for the unprivileged farmers. The list of benefits a cultivator can get:

- It is reasonable and sustainable.

- It is transportable.

- Farmer is needed to be present on the farming land.

- Chemicals like pesticide does not harm the robot.

- It operates on batteries, so no use of any fuel.

- Completely automated after entering the dimensions of the field.[1]

\section{FUTURE WORK}

For the future, the project can accomplish with tremendous outcomes in large scale that will benefit each farmer. Apart from seed dispensing, ploughing, and harvesting, other processes like showering pesticides, fruit picking, and so can be accomplished in one robot and thus we can make this robot skilled and multitasking. As we know Raspberry Pi is most used version nowadays so it could be used in future rather than using Arduino Uno for greater development of the robot.[1] Also, we are planning to add few extra features as seed dispensing, harvesting and ploughing like inserting Go-pro camera to get updates of the field, having crop audit system Ithat will tell the farmer if the crops are in good shape or not, having a robotic arm to pick and drop fruits and also escort the farmers to plant in efficient manner. We might add large harvester to the robot for increasing the cultivation. The leading future goal of this agrobot would be the detection of weed using image processing in which robot will detect the weed between the crops by just capturing the image. For further modifications, we will try and make this agrobot extra qualified and less in economics thence, all kind of agriculturist can operate this robot to cultivate their farmland and develop healthy crops. We also have some huge arrangement for this robot that makes it smoothly available for large scale cultivation which can be done using multiple robots at the same time using master-slave approach. This can be done effectively and with better reliability lessen the unnecessary load on farmers and making their life easy.

\section{CONCLUSION}

The Agrobot is created by keeping clear in mind for inadequate and needful farmers and it is specifically designed to accomplish the things like reducing load of farmers so that their pain can be reduced and productivity can be increased. Agrobots can entirely change the face of traditional farming practices by changing its look, feel and pace. It can significantly change the outlook of the agricultural sector over the next decade especially where the consumers demand and requirements of labor is at its peak. It is an autonomous farming robot which have the potential to work precisely under extreme conditions having continuous monitoring by using variety of sensing technology. We can easily enter the dimensions of field and the mode which has to be performed and this robot will easily accomplish its task. This robot is worth it as its equipment's are much reasonable and cost effective. Also, this is much eco-friendly than old methods. Various technologies like image processing can also be used with it for enhancing the capacity and effectiveness of this robot as it will give optimal solutions for various agricultural operations and thus, we can shape the interest of new generation in agricultural area which will be beneficial for the country.

\section{REFERENCES}

[1] DIDARU MD., SUJON ISLAM, NASIR RUMMAN, MOZAMMEL MAHBUBE, HABIB IBNE, ISLAM NOMAAN MAJDEUL, BAIDYA JAYASREE, REZAU MD.,(2019) ISLAM DEPARTMENT OF ELECTRICAL AND COMPUTER ENGINEERING INTERNATIONAL CONFERENCE ON INTELLIGENT AUTONOMOUS SYSTEMS VOLUME: 06 ISSUE: 03

[2] SRIVASTAVA PAYAL, NEDA KIRTI, (2018) ELECTRONICS AND INSTRUMENTATION ENGINEERING GALGOTIAS COLLEGE OF ENGINEERING AND TECHNOLOGY, GR. NOIDA, INDIA IJEDR INTERNATIONAL CONFERENCE ON INTELLIGENT AUTONOMOUS SYSTEMS VOLUME 5, ISSUE 2 | ISSN: 2321-9939

[3] SALAMA SAMI, HAJJAJ HUSSEN, SALLEH KHAIRUL, SAHARI MD.(2018) CENTRE FOR ADVANCED MECHATRONICS AND ROBOTICS UNIVERSITI TENAGA NASIONAL 43000 KAJANG, SELANGOR, MALAYSIA

[4] KAVITHRA M., SHALINI S., DHANUSHA A., VANIKAMATCHI T., SURESH S. (2018) INTERNATIONAL JOURNAL OF ENGINEERING RESEARCH \& TECHNOLOGY (IJERT) ISSN: 22780181

[5] KHERADE D. NEHA ,KUTE JYOTI , PASHTE POOJA, MARYE PRANITA PROF. DR. MEHTA SAURABH (2017) HEAD OF THE DEPARTMENT, DEPT. OF EXTC, VIDYALANKAR INSTITUTE OF TECHNOLOGY, MUMBAI E-ISSN (O): 2348-4470 P-ISSN (P): 23486406 SCIENTIFIC JOURNAL OF IMPACT FACTOR (SJIF): 4.72 VOLUME 4 ISSUE -3

[6] ROUT RUTVEEZ ROOPAM , SRINATH B., BISHT VISHAL, BHARDWAJ SHUBHANKAR, JOSSY MARIA A., (2017) DEPARTMENT OF ELECTRICAL AND COMMUNICATION ENGINEERING SRM UNIVERSITY, CHENNAI, TAMILNADU, VOLUME ISSUE NO.4 INDIA ISSN IJESC 
[7] RAJESH K. (2017) AG-ROBOT DESIGN AND ANALYSIS TO LIGHT WEIGHT STANLEY COLLEGE OF ENGINEERING AND TECHNOLOGY FOR WOMEN, HYDERABAD, INDIA IJSRD INTERNATIONAL JOURNAL FOR SCIENTIFIC RESEARCH \& DEVELOPMENT| VOL. 5, ISSUE 09 | ISSN (ONLINE): 2321-0613

[8] PRASEENA S, SANJENA S, THEJASWINI S. M , SENTHAMIL M., (2017) DEPT OF INFORMATION TECHNOLOGY 4HEAD OF DEPARTMENT , DEPT. OF INFORMATION TECHNOLOGY, SRI RAMAKRISHNA ENGINEERING COLLEGE, TAMIL NADU, INDIA INTERNATIONAL RESEARCH JOURNAL OF ENGINEERING AND TECHNOLOGY VOL. 5, ISSUE 09 P-ISSN: 2395-0072

[9] SONIMINDIA LAXMI, TAWARE, SHRUTI, SINHA SHREYA. KUMBHAR V.S. (2017)(ELECTRONICS AND TELECOMMUNICATION, PIMPRICHINCHWAD COLLEGE OF ENGINEERING AND RESEARCH, INDIA) IOSR JOURNAL OF ENGINEERING (IOSR JEN)

[10] KHANDELWAL SHUBHAM, KAUSHIK NEHA, SHARMA SAGAR(2017) B.TECH ECE, AMITY UNIVERSITY HARYANA, INDIA issn no. 0976-5697 VOLUME 8, NUMBER 5 MAY-JUNE

[11]PEDERSEN STUDYS M, FOUNTAS S., HAVE H. BLACKMORE B.S. DANISH AGRICULTURAL ROBOTS: AN ECONOMIC FEASIBILITY RESEARCH INSTITUTE OF FOOD ECONOMICS, KVL, ROLIGHEDSVEJ , 1958 FREDERIKSBERG C, DK2DEPARTMENT OF SOIL SCIENCE, KVL, HOJBAKKEGAARD ALLE 2, 2630

[12] RAJA J, \& STANLEY W, KARUNAKARAN (ASP/ECE, M.A.M COLLEGE OF ENGINEERING, TRICHY, INDIA). IOSR JOURNAL OF ELECTRONICS AND COMMUNICATION ENGINEERING (IOSR-JECE) E-ISSN: 2278-2834,P-ISSN: 2278-8735 PP 68-73

[13] MUTHARASU, DIVYA V. VDIVYA VIVEKANANDHA COLLEGE OF ENGINEERING FOR WOMEN (AUTONOMOUS), TIRUCHENGODE, TAMIL NADU ISSN: 2454-132X IMPACT FACTOR: 4.295 (VOLUME 5, ISSUE 2) MUTHARASU S. ET AL.; INTERNATIONAL JOURNAL OF ADVANCE RESEARCH, IDEAS AND INNOVATIONS IN TECHNOLOGY

[14] GRIEPENTROG H.W., SKOU P.T., SORIANO J.F., BLACKMORE B.S. THE ROYAL VETERINARY AND AGRICULTURAL UNIVERSITY (KVL), FREDERIKSBERG / COPENHAGEN, DENMARK EMAIL: HWG@KVL.DK POLYTECHNIC UNIVERSITY OF MADRID, MADRID, SPAIN

[15].SURESH, R., GOPINATH S, GOVINDARAJU K, DEVIKA T., SUTHANTHIRAVANITHA N.,(2014)“GSM BASED AUTOMATED IRRIGATION CONTROL USING RAINGUN IRRIGATION SYSTEM”, INTERNATIONAL JOURNAL OF ADVANCED RESEARCH IN COMPUTER AND COMMUNICATION ENGINEERING VOL. 3, ISSUE 2, FEBRUARY 